И нақонец, в системе Организации Объединенных Наций, по моему мнению, должен быть создан специализированный орган по контролю за использованием морских живых ресурсов в морях и океанах, независимый орган, но при Организации Объединенных Наций. Я разделяю те опасения, о которых здесь говорил по этому вопросу профессор Бекяшев, но без такого органа мы не двинемся в XXI век.

В заключение я, пользуясь случаем, хотел бы поблагодарить вас от имени рыбаков России за те усилия в области международного права, котрые дают нам возможность надеяться, что в XXI веке мы все-таки вступим в эпоху сотрудничества, в эпоху устойчивого развития морского рыболовства во всех морях и океанах.

\title{
СОВРЕМЕННОЕ ПИРАТСТВО
}

\author{
Барри Харт Дабне
}

Хотел бы отановиться на насилии на море и на современном пиратстве. Буду базироваться на различных документах, которые уже приняты в этой области, а также на Конвенции об открытом море, которая рассматривала пиратство только с практических позиций. 'Гакже буду ссылаться на свою докторскую диссертацию, которая тоже была посвящена этим вопросам. Тогда я преподавал в Австралии, писал эту диссертацию исключительно из любопытства. Меня тогда очень беспокоили вопросы окружающей среды и то, как они повлияют на международную безопасность. Тогда уже существовали страны, которые беспокоились по поводу растущего количества случаев пиратства. И хотя обычное законодательство о пиратстве рассматривалось всего лишь как рядовой случай терроризма на море, таким образом, можно было трактовать пиратство просто как рядовой случай, как терроризм, который может существовать где угодно.

Почему же именно о современном пиратстве говорим мы сегодня? Потому, что пиратство - это не только экономическая проблема. Пиратство может внести сумятицу и хаос в проблемы судоходства и создать серьезную угрозу на море. Прежде чем пойти дальше, я хотел бы сказать о нескольких терминах, которые буду употреблять в своем докладе.

Когда мы говорим о пиратстве, мы говорим о насилии, ограблении или задержании, которое совершается в личных интересах и

* Профессор Школы права Томаса М. Кули, штат Мичиган (США). 
происходит в открытом море. Терроризм, например, в обычном понимании может существовать и на земле, а морское насилие может существовать где угодно в море. Это, можно сказать, родовой или всеобъемлющий термин - морское насилие.

Обычно я говорю также 06 исторической подоплеке пиратства, об истории этого вопроса, о том, как пиратство развивалось. Имеются различные подходы, ортодоксальные и не ортодоксальные, $к$ трактованию самого понятия пиратства. Мы уже говорили о том, что Конвенция, заключенная по этому поводу, придает практическое толкование проблеме пиратства. Часто можно услышать мнение, что пиратство - это не международное преступление и посему носит весьма ограниченный характер.

Макси Фарли, например, провел статистический анализ и выпустил труд, создал базу данных, которая охватывает все акты пиратства до 1993 года. Это пиратские акты, которые он относит именно к этому конкретному виду насилия. Мехдународное право трактует пиратство как нападение одного корабля на другой в открытом море.

Некоторые считают, что пиратство - это местное явление. В статистическом анализе, о котором мы говорили, все акты пиратства подразделяются на 12 регионов. Кроме того, они подразделяются по тому, происходят ли они в открытом море или в территориальных водах. Пиратство в основном развито в Юго-Восточной Азии, и охоло 500 зарегистрированных актов пиратства произошли именно здесь. Это - статистика за последние пять лет.

Ученый, о котором я говорил, базировал свои данные на изучении массы материалов морской разведки, Топографического центра, Министерства энергетики Соединенных Штатов и так далее.

Сэмюэл Менефи, один из профессоров, которые работают в Университете Вирджинии, считает, что пиратство не представляет собой экономическую угрозу для судоходства, это всего лишь частный акт насилия. И тот ущерб, который наносит сегодня пиратство, практически незаметен по сравнению с теми привычными нам угрозами, которые представляют различные другие типы насилия. И даже в регионах, где пиратство развито, экономический ушерб от него низок.

Интересно отметить, что очень часто владельцы судов не сообшают об актах пиратства, поскольку боятся, что это бросит тень на ситуацию на судне, на дисциплину на судне. И, кроме того, некоторые из них считают, что если они сообщат $\infty$ акте нападения, то таким образом повысят угрозу быть повторно ограбленными пиратами. Кроме того, вопросы страховки здесь также играют большую роль, поскольку за прохождение через территориальные воды, где риск выше, чем в среднем, страховка тоже выше. 
Кроме того, господин Фарли говорил также о том, что для окружающей среды пиратство не представляет большой угрозы, поскольку достаточно ограниченное число нападений было зарегистрировано за все последние годы. Однако пиратство развивается, и случаев пиратства становится все больше. Обычно пираты выбирают для своих нападений танкеры, это самый частый случай пиратства. Во время таких атак они редко крадут грузы, чаще всего предпочитают забирать личное имущество команды или деньги. Очень часто пираты, нападая на корабль, задерживают команду, и тогда в течение какого-то времени судно остается без управления, поскольку нарушаются средства связи и навигации. Н 25 процентов пиратских нападений приходится именно на различные виды танкеров. Иногда грузы являются целью нападения пиратов, особенно это касается нефтяных танкеров, но, даже когда груз захватывается пиратами, разлив нефти в районе Аляски приносит значительно больше ушерба, чем захват такого танкера. И даже в районе Сингапура, где по-настояшему насышенный район судоходства, не так много случаев пиратства, хотя их больше, если смотреть в целом на весь мир.

Господин Фарли в свое исследование включил суда, которые подвергались нападениям пиратов на расстоянии 30 морских миль от берега. Как правило, целью пиратов было ограбление. Все случаи пиратства были разбиты на те, которые осуцествляются в территориальных водах, и на те, которые происходят в открытом море. Однако каким-то образом систематизировать эти категории было достаточно трудно, поскольку несколько государств претендуют на одни и те же территориальные воды, и именно в этом регионе, где больше всего пиратских нападений, труднее всего каким-то образом представить себе полную картину того, что происходит. Иногда пираты нападают на беженцев и на частные суда, однако эти случаи не попали в исследование, которое провел господин Фарли.

Мы рассмотрели 54 процента случаев всех пиратских нападений. В течение определенного периода времени было 7 судов, которые находились под командой неизвестно кого, они не были зарегистрированы, и произошло это в районе, где очень развито судоходство. Большинство случаев пиратских нападений имеет место в территориальных водах государств в ночное время. Поэтому оказывается, что суда бывают в безопасности в течение 7 процентов времени, а в 48 процентах случаев пираты покидают суда, ничего не забрав. Статистика показывает, что в тех случаях, когда пиратов увидели до захвата судна, кораблю, который должен был подвергнуться нападению, удавалось уйти. В 15 процентах случаев случалось так, что члены экипажа гибли. В Юго-Восточной Азии 
обычно погибает около 15 процентов членов экипажа, которые оказывают сопротивление пиратам. Но в том случае, когда все экипажи сопротивляются, количество смертей в 2 раза больше. Было сообщение о том, что в 18 случаях из 272 имелись раненые, причем это случилось в те моменты, когда экипаж оказывал сопротивление. Руководство нападением обычно ведется на расстоянии, с берега, там, где происходит акция захвата. Например, в районе Индонезии среднее расстояние, с которого производится нападение с берега, составляет всего 11,5 морских миль. В Юго-Восточной Азии эти нападения случаются даже и на большем расстоянии, примерно 50 морских миль. Часто нападают на коммерческие рыболовецкие суда, причем рыбаки обычно считают нападающих или же таможенными чиновниками, или же представителями пограничного патруля.

В заключение несколько слов о том, как можно решить экологическую проблему. Единственно, что я могу предложить, хотя предложение совершенно нереалистичное, - поставить охранника на каждый корабль, так же как ставят лоцмана. Но я думаю, что моряки со мной не согласятся. В своей книге я много раз говорил, что нельзя допускать преступления в территориальных водах других государств. Обычно этим никто не занимается, потому что возникает вопрос о нарушении территориальной целостности.

Что касается России, то у меня есть несколько случаев и по России. С 31 декабря 198? г. 27 судов под российскими флагами подвергались таким нападениям. Было три инцидента в марте 1995 года. Один из российских кораблей был просто угнан, на борту находилось 24 члена экипажа. Местные власти не сумели обеспечить охрану этого судна от нападения местных пиратов. Это был грузовой корабль, который стал жертвой пиратского нападения. Такое же нападение было в июне 1994 года. В июне 1995 года подвергся нападению украинский сухогруз. Международное морское бюро дает эту информацию раз в квартал и, естественно, в хронологической последовательности. 